\title{
O Mar da Galileia e seus contextos de simbolismos
}

\author{
El Mar de Galilea y sus contextos de simbolismo \\ The Sea of Galilee and its contexts of symbolism
}

\author{
Elsbeth Léia Spode Becker ${ }^{1}$ \\ Natália Lampert Batista ${ }^{2}$
}

Augusto Russini ${ }^{3}$

\begin{abstract}
Resumo
O artigo descreve o Mar da Galileia e seu entorno no contexto bíblico. Após uma breve apresentação geográfica da região, buscou-se traçar os rumos da história, enfocando, especialmente, o contexto do Cristianismo, evidenciando o ambiente natural dos apóstolos que Jesus convidou para pescar homens e almas. A metodologia está embasada na revisão bibliográfica na perspectiva da pesquisa qualitativa que relaciona a história e a geografia como interação com a experiência no sagrado e a atividade do turismo. Concluiu-se que a história antiga no Mar da Galileia e seu entorno é uma terra de contrastes de religiões e de culturas onde os peregrinos e, também, os turistas buscam a experiência de fé que é visível na geografia e nas ruínas das antigas cidades de Carnafaum, Tiberíades, Magdala, Corazim e Betsaida. O sagrado e o profano coexistem, porém torna-se difícil distinguir os seus limites. O sagrado está nos símbolos que são abrigados pelas igrejas construídas no local para a realização dos ritos de fé. O espaço profano é o entorno, o espaço destinado ao comércio e ao lazer.
\end{abstract}

Palavras-chave: Lago de Tiberíades; Carnafaum; Tiberíades; Magdala; Corazim; Betsaida.

\section{Resumen}

El artículo describe el Mar de Galilea y su entorno en el contexto bíblico. Después de una breve presentación geográfica de la región, se buscó trazar los rumbos de la historia, enfocando especialmente el contexto del Cristianismo, evidenciando el ambiente natural de los apóstoles que Jesús invitó a pescar hombres y almas. La metodología está fundamentada en el estado del arte y en la perspectiva de la investigación cualitativa que relaciona la historia y la geografía como interacción con la experiencia en lo sagrado y la actividad del turismo. Se concluyó que la historia antigua en el Mar de Galilea y su entorno es una tierra de contrastes de religiones y

\footnotetext{
${ }^{1}$ Graduação em Geografia (Bacharelado) pela Universidade Federal de Santa Maria (UFSM - 1996), Graduação em Geografia (Licenciatura Plena) pela UFSM, Mestrado em Engenharia Agrícola Área das Ciências Rurais pela UFSM (1999) e Doutorado em Agronomia pela UFSM (2008). Atualmente é Professora adjunta no Centro de Ciências Humanas do Centro Universitário Franciscano e professora da rede pública estadual atuando no Ensino Médio em Santa Maria, RS. E-mail: elsbeth.geo@gmail.com.

${ }^{2}$ Graduação em Geografia (Licenciatura) pelo Centro Universitário Franciscano (2013), Mestrado em Geografia pelo Programa de Pós-graduação em Geografia (PPGGeo), da Universidade Federal de Santa Maria (UFSM 2015). Atualmente é Doutoranda em Geografia pelo PPGGeo/UFSM. Atualmente é Professora na rede municipal de Santa Maria, RS. E-mail: natilbatista3@gmail.com.

${ }^{3}$ Graduação em História Licenciatura Plena pela UNIFRA, Graduação Tecnológica em Processos Gerenciais pelo Centro Universitário de Maringá/PR (UNICESUMAR) e Pós-Graduação em Ensino e Pesquisa em História pela UNIFRA. Atualmente é mestrando em Ensino de Humanidades e Linguagens no Centro Universitário Franciscano (UNIFRA). Atualmente é Diretor Administrativo e Pedagógico em escolas da Rede Privada de Ensino de Santa Maria, RS. E-mail: augustorussini.sm@gmail.com.
} 

e-ISSN 2016/Atual: 2525-7870 | e-ISSN 2015/2016: 2447-018X

de culturas donde los peregrinos y también los turistas buscan la experiencia de fe que es visible en la geografía y las ruinas de las antiguas ciudades de Carnafaum, Tiberíades, Magdala, Corazín y Betsaida. Lo sagrado y lo profano coexisten, pero resulta difícil distinguir sus límites. El sagrado está en los símbolos que son abrigados por las iglesias construidas en el lugar para la realización de los ritos de fe. El espacio profano es el entorno, el espacio destinado al comercio y al ocio.

Palabras clave: Lago de Tiberíades; Carnafaum; Tiberíades; Magdala; Corazin; Betsaida.

\begin{abstract}
The article describes the Sea of Galilee and its surroundings in the biblical context. After a brief presentation of the geographic region, sought to trace the course of history, focusing especially the context of Christianity, showing the natural environment of the apostles that Jesus invited to fish men and souls. The methodology is based in the state of the art and perspective of qualitative research that relates the history and geography as interaction with the sacred experience and tourism activity. It was concluded that the ancient history of the Sea of Galilee and its surroundings is a land of contrasts of religions and cultures where pilgrims and tourists seek the experience of faith that is visible in geography and in the ruins of ancient cities of Carnafaum, Tiberias, Magdala, Chorazin and Bethsaida. The sacred and the profane coexist, but it is difficult to distinguish its limits. The sacred is in symbols that are housed by the churches built on the local to execute the rites of faith. The profane space is the environment, the space for trade and leisure.
\end{abstract}

Keywords: Lake Tiberias; Capernaum; Tiberias; Magdala; Chorazin; Bethsaida.

\title{
1. Introdução
}

O mar é uma grande extensão de água salgada conectada com o oceano, ou, então, situada no interior do continente. No caso, o Mar da Galileia (ou Lago de Tiberíades), é considerado um mar fechado, que não apresenta comunicação alguma com o oceano, constituindo um vasto lago de águas que sofre absoluta influência das terras continentais que o circundam. Localiza-se no Oriente Médio (figura 1). 


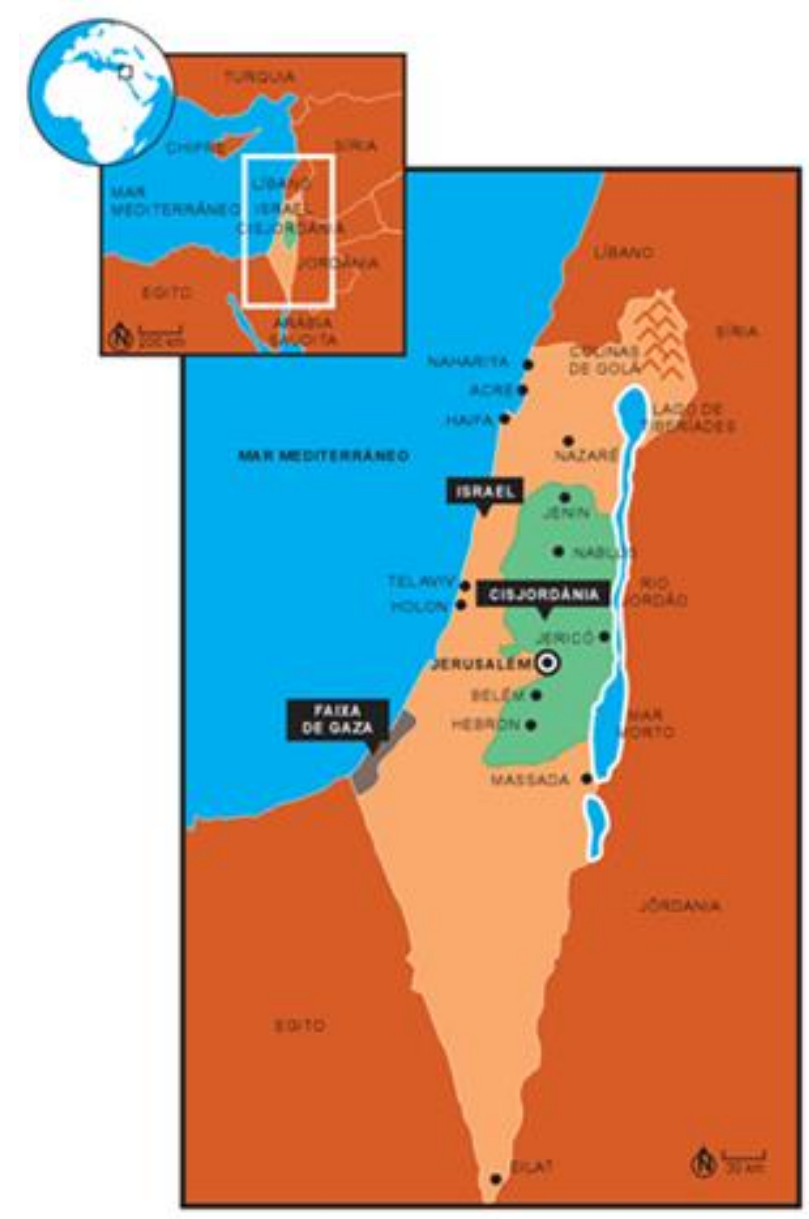

Figura 1. Localização geográfica do Mar da Galileia (Lago de Tiberíades) no Oriente Médio. Fonte: HARTMANN, 2015 (adaptado).

O Mar da Galileia é o maior lago de Israel e faz fronteira entre Israel, Cisjordânia e Jordânia. Tem, aproximadamente, 21 quilômetros de largura, 13 quilômetros de comprimento, situado a 212 metros abaixo do nível do Mar Mediterrâneo e tem uma profundidade máxima de 45 metros (HARTMANN, 2015). Recebe água de seu principal tributário, o rio Jordão, que é também o seu efluente a sul, drenando para o Mar Morto, formando com este o conjunto mais notável de acidentes geográficos no vale do rio Jordão (figura 2). O rio Jordão nasce na encosta do Monte Hérmon, na Jordânia e o seu vale constitui um significativo trecho de fronteira entre Israel e Jordânia. Sua principal característica é a salinidade que se acentua no seu trecho a jusante, após ser efluente do Mar da Galileia até desembocar no Mar Morto.

Assim como o Morto, o Mar da Galileia é uma fenda tectônica e foi formado pela separação das placas tectônicas Africana e Arábica. Consequentemente, a região encontra-se sujeita a atividade sísmica, e, no passado, também sofreu derrames vulcânicos, que é evidente na paisagem, dada a quantidade de basalto e de outras rochas ígneas que caracterizam a geologia da Galileia. 


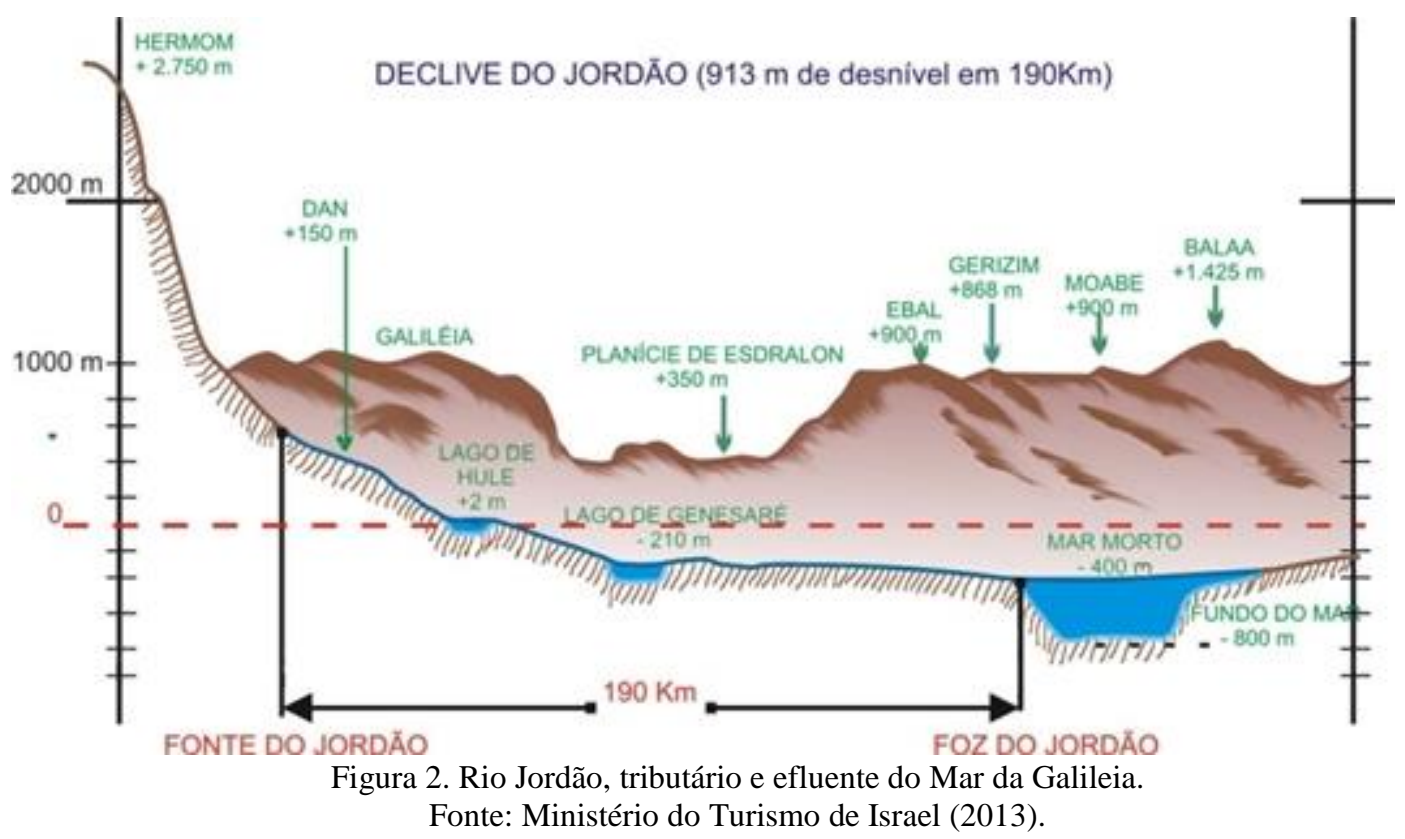

No Velho Testamento (Números 34:11; Josué 13:27), o Mar da Galileia, é chamado de Kinneret e deriva da palavra kinnor, que no hebraico, significa harpa, porque seu formato natural se assemelha a forma de uma harpa ou lira cristã. Ainda recebe as denominações de Lago de Tiberíades e de Lago de Genesaré ou Guinossar.

No tempo do Novo Testamento, há 2mil anos), nas proximidades do Mar da Galileia (figura 3), ficavam cidades importantes politicamente e socialmente e que foram cenários de célebres passagens bíblicas e berço de importantes personagens do início do Cristianismo, como Carnafaum, Tiberíades, Magdala, Corazim, Betsaida e, também, o local da multiplicação dos pães. Portanto, essa região e o Mar da Galileia foram testemunhas ativas na história da Antiguidade e o ambiente natural dos apóstolos que Jesus convidou para pescar homens e almas. 

e-ISSN 2016/Atual: 2525-7870 | e-ISSN 2015/2016: 2447-018X

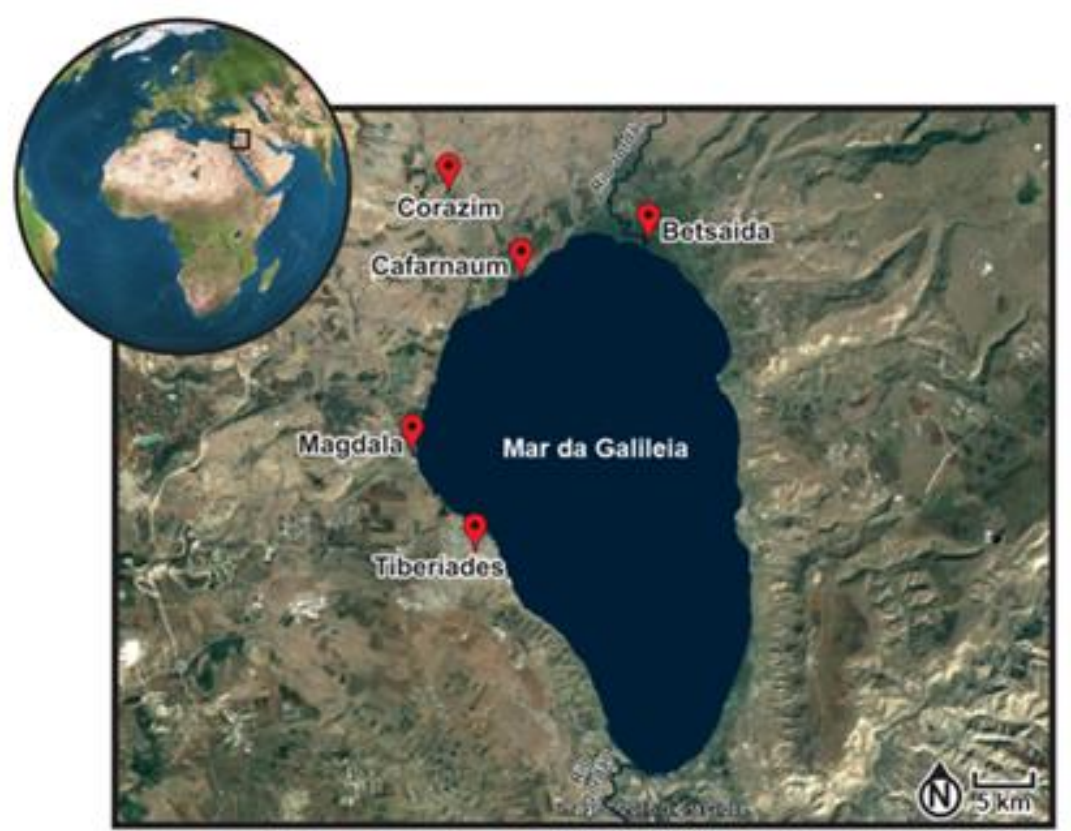

Figura 3. Mar da Galileia e a localização das cidades de Carnafaum, Tiberíades, Magdala, Corazim, Betsaida Fonte: Google (adaptado).

Neste artigo descreve-se uma interpretação geográfica da manifestação do sagrado no Mar da Galileia e seu entorno. A experiência de fé é tão visível quanto emocionante e revela um simbolismo marcante, que ultrapassa qualquer concepção, seja ela tradicional ou pósmoderna, de experiência espiritual. A questão central é evidenciar a ligação do sagrado na paisagem e mostrar o viés compreendido entre o sentido cósmico da existência de Deus no mundo, manifestando-se na natureza; e reconhecer a existência de um sistema de relações entre o homem e a fé, e suas práticas materializadas no espaço geográfico.

\section{BREVE CONTEXTO DA REGIÃO DO MAR DA GALILEIA}

\subsection{A Galileia no contexto bíblico}

A palavra "galileia" vem do hebraico galil, empregada desde o Antigo Testamento, que significa círculo ou distrito. Atualmente, é uma região que pertence ao Estado de Israel e integra a maior parte do Distrito Administrativo do Norte do país.

A região da Galileia se estendia até o Monte Carmelo a sudoeste; a sudeste até Citópolis; ao nordeste até o Monte Hermon e ao norte até Tiro. A leste era limitada pelo rio Jordão e pelo Mar da Galileia. A parte norte era denominada a Galileia superior, que compreendia as áreas de terras mais altas e ao sul, a Galileia inferior. Há dois mil anos, no lago e seu entorno estava a sobrevivência de muitas famílias que viviam da pesca e, a Galileia, foi a província de maior destaque na vida terrena de Jesus. Compreende-se, facilmente, que dos doze homens que Jesus 
escolheu para discípulos, quatro fossem pescadores, conforme relatado em Mateus (4:18-22) e em Lucas (5:1-11): "E Jesus, andando ao longo do mar da Galileia, viu dois irmãos, Simão, chamado Pedro, e seu irmão André, os quais lançavam redes ao mar, porque eram pescadores. Disse-lhes: Vinde após mim, eu vós farei pescadores de homens. Eles, pois, deixando imediatamente as redes, o seguiram. E, passando mais adiante, viu outros dois irmãos - Tiago e seu irmão João, no barco com seu pai Zebedeu, consertando as redes; e os chamou. Estes, deixando imediatamente o barco e seu pai, seguiram-no".

O cenário do Mar da Galileia vai aparecer em vários episódios da vida de Jesus, como, por exemplo, o 'sermão das montanhas' (Mateus 5:1-12) que, provavelmente tenha sido feito em uma colina com vistas para o lago.

O lago era intensamente utilizado tanto para navegação como para a prática da pesca. $\mathrm{O}$ próprio Jesus Cristo atravessou várias vezes o lago e em uma delas, andando sobre as águas, conforme relatam os sinópticos, como um dos milagres realizados pelo Mestre. Entre os milagres de Jesus, está 'o andar de Jesus sobre as águas' (Marcos 6:45-52), (Mateus 14:22-36) e (João 6:16-21); o 'acalmar a tempestade' (Lucas 8:22-25), (Mateus 8:23-27) e (Marcos 4:3541); a 'pesca milagrosa' (Lucas 5:1-11) e 'alimentar uma grande multidão com apenas dois peixes e cinco pães' (Mateus 8:27); (Marcos 4:41; Lucas 8:25).

O lago era muito piscoso e, por isso, intensamente utilizado pelos pescadores. Na época de Jesus, os pescadores eram uma das classes mais baixas em nível social. A classe mais desprezada, todavia, era a dos pastores, a ponto de Jesus se sensibilizar e se autointitular 'Bom Pastor'. Mas, é com os pescadores que Jesus tem a maior convivência. Jesus não só escolhe uma parte dos apóstolos entre eles, mas suas pregações usam exemplos de sua vida cotidiana, como por exemplo, quando compara o Reino de Deus a uma rede jogada no mar e depois os pescadores separam os peixes bons dos que não prestam (Mateus 13:47-50). De fato, no Antigo Testamento, no livro de Levítico 11:10, está escrito que o judeu não pode comer peixe sem escamas, como por exemplo, a espécie catfisch ${ }^{4}$ que, atualmente, o israelita pesca e vende para consumidores de outras crenças que não o Judaísmo.

\subsection{O Mar da Galileia, a história e o turismo}

\footnotetext{
4 O catfish (Ictaluruspunctatus) é um peixe representante da ordem Siluriformes, família Ictaluridae, caracterizando-se por não possuir escamas, apresentar barbilhões sensitivos e ser onívoro.
} 
O Mar da Galileia, por sua paisagem geográfica e histórica, é referência para diferentes interesses, desde a arqueologia, o simbolismo da fé até a economia turística. Essa região, o Mar e seu entorno, são roteiros para peregrinos e turistas, em suas diferentes motivações.

A embarcação resgatada do fundo do Mar da Galileia é um exemplo ilustrativo para entender a dinâmica da região, em suas relações geográficas, econômicas, religiosas e históricas. Nos períodos anuais de estiagem (nos meses de maio até setembro), o Mar da Galileia reduz sensivelmente seu nível de água e, nas últimas décadas, esse nível fica reduzido a níveis críticos em função da escassez de água na região e da utilização das nascentes do Rio Jordão para a irrigação. Assim, durante o período seco do ano de 1986, o nível do lago baixou, como normalmente acontece, a linha d'água se afastou, fazendo a margem maior e dois pescadores do kibutz ${ }^{5}$ de Guinossar - cidade às margens do Mar e que, antigamente, era a Genesaré bíblica (Mateus 14:34) - que pescavam no lago, com redes, notaram parte de um objeto estranho emergindo da lama. O pescador Yuvi Lufan é, também, escultor e jardineiro no kibutz e, junto com seu irmão Moshe, descobriu o barco. Segundo Yuvi “o amor pelo Mar da Galileia é cultural e passa de geração em geração. Nossos pais nos ensinaram a amar o Mar da Galileia e achar o barco foi um presente especial para o mundo todo" (MINISTÉRIO DO TURISMO DE ISAREL, 2013).

O barco foi identificado, pelos arqueólogos, como sendo uma embarcação de pesca e de passageiros de, aproximadamente, 2 mil anos atrás. Essa constatação contribuiu para que a denominação popular para a embarcação remetesse o objeto aos tempos de Jesus e, assim, ficou sendo o "Barco de Jesus", por ser bem semelhante aos que o Messias utilizava naquela área com seus discípulos, inclusive em importantes passagens da Bíblia, como a que andou sobre as águas (Mateus 14), ou aquela em que acalmou uma tempestade (Mateus 8). O barco passou por uma complexa e longa restauração e, atualmente, está exposto para visitação (figura 4a) no museu do Centro Yigal Alon (figura 4b, c, d), no kibutz de Guinossar.

\footnotetext{
${ }^{5}$ Kibutz é uma forma israelense de vida em comunidade, em fazendas coletivas, inspirada na ideologia socialista. Seus membros partilham o trabalho, o consumo e a educação.
} 

e-ISSN 2016/Atual: 2525-7870 | e-ISSN 2015/2016: 2447-018X

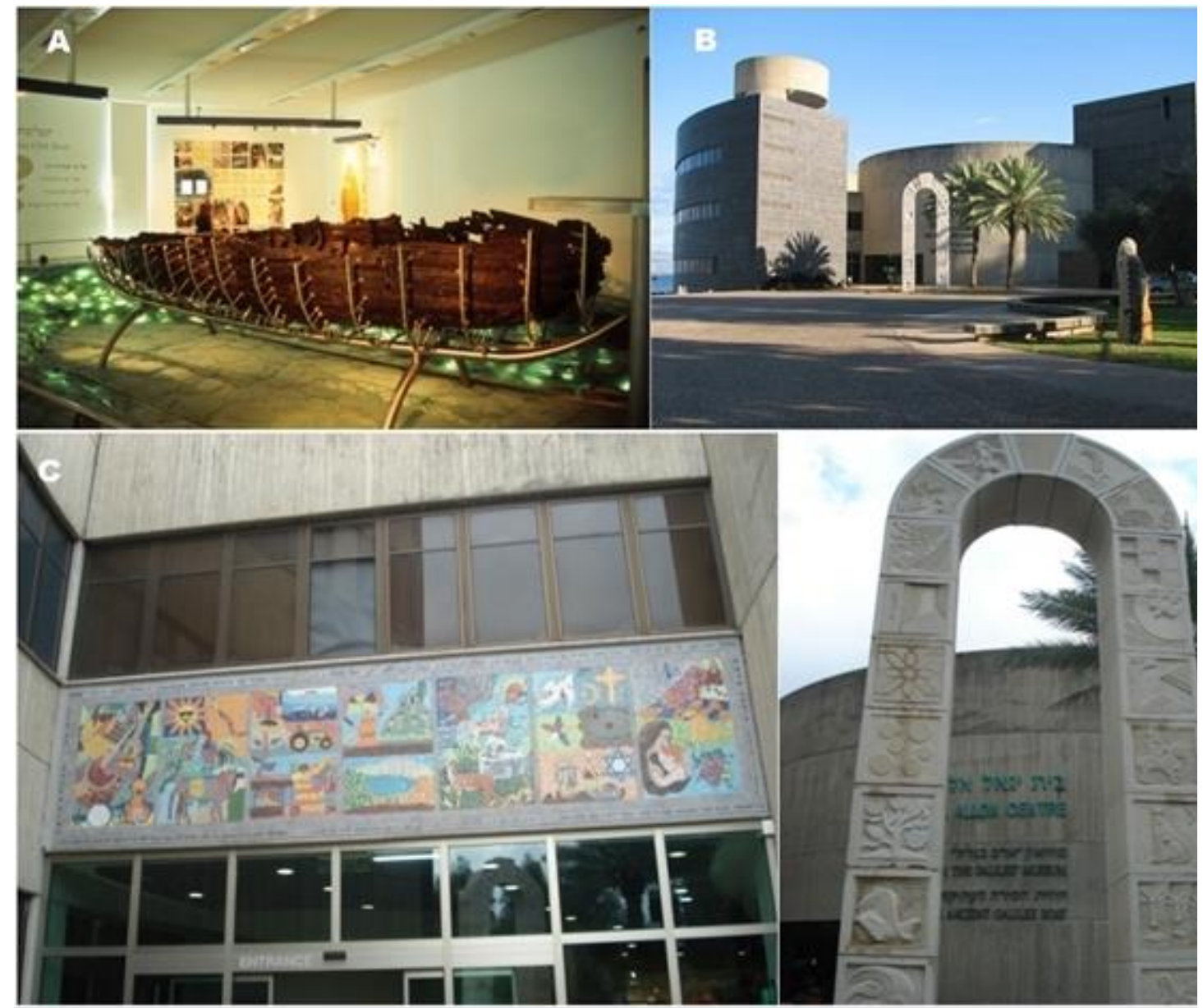

Figura 4. 2a). Embarcação denominada 'Barco de Jesus'; 2b) Museu Yigal Alon. 2c) Painel na Entrada principal do Museu Yigal Alon; 2d) Entrada principal do Museu Yigal Alon. Fonte: Arquivo pessoal. Fevereiro/2013

No museu de Yigal Alon, no kibutz de Guinossar, existe uma espécie de ancoradouro, com várias embarcações disponíveis para o turismo. Esse ancoradouro é administrado pelos moradores da comunidade do kibutz de Guinossar. Os turistas são embarcados e, logo após, a embarcação zarpar, é entoado o Hino Nacional do país de origem dos turistas e hasteada a respectiva bandeira. A bandeira de Israel permanece no mastro. Em seguida, é jogado ao Mar, alimento para as gaivotas que voam e 'aterrissam' na água, oferecendo um imaginário ímpar aos turistas (figura $5 \mathrm{a}$ e b).

Em dois mil anos de história, houve grande transformação no planeta e, também, na Terra Santa, mas o céu azul, o lago e os montes que o circundam são sempre os mesmos. Quando os turistas fazem a travessia de barco, normalmente do kibutz de Guinossar até Tiberíades, todos admiram encantados e emocionados a paisagem do lago e seu entorno, olhando em todas as direções para imprimir bem na mente e no coração uma paisagem vista por Jesus há dois mil anos. O Mar da Galileia, como no tempo de Jesus, tem peixes. O mais 
RELACult - Revista Latino-Americana de Estudos em Cultura e Sociedade

Revista Latinoamericana de Estudios en Cultura y Sociedad | Latin American Journal of Studies in Culture and Society V. 03, no 02, mai-ago., 2017, p. 77-100| relacult.claec.org e-ISSN 2016/Atual: 2525-7870 | e-ISSN 2015/2016: 2447-018X

famoso é a tilápia chamada "peixe de São Pedro", servido no restaurante do kibutz de Ein Gev e, também, em outros restaurantes em torno do Mar da Galileia.

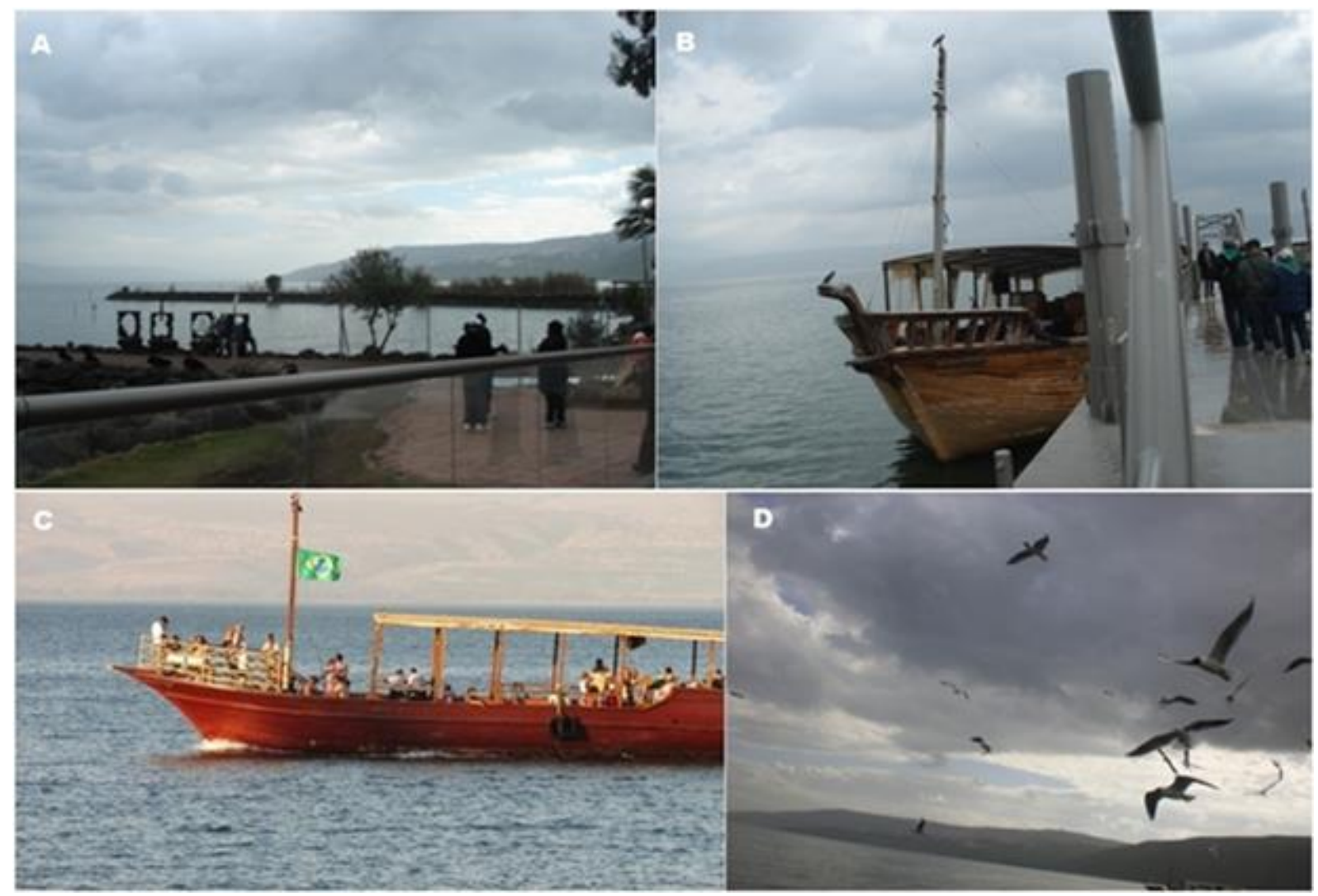

Figura 5a e b) Ancoradouro no Mar da Galileia, no Museu de Museu Yigal Alon, Kibutz de Guinossar; 5c) Barco com turistas brasileiros; 5d) Gaivotas.

Fonte: Arquivo pessoal. Fevereiro/2013 (figuras a, b e d). Ministério do Turismo (2013) (figura c).

Os moradores que formam as pequenas comunidades dos kibutzim, como o kibutz de Guinossar e o kibutz de Ein Gev, são de origem judaica e desenvolvem atividades agrícolas atreladas à vida rural, à pesca e o turismo, oferecendo o passeio no Mar da Galileia. Vivem em harmonia com a natureza e são, especialmente, amorosos com todas as formas de vida e ao trabalho que desempenham, combinando comprometimento com o igualitarismo e cuidado com a natureza. Guinossar, assim como os demais kibutzim, começaram como fazendas coletivas e, por isso, ocupam as regiões mais bonitas e mais férteis de Israel. Segundo o Ministério do Turismo (2013), atualmente, apenas uma pequena parcela da população judaica, 1,5\% do total de 7.908 milhões de habitantes, em 2012, vive em kibutzim e se dedicam as atividades coletivas. Atualmente existem 207 kibutzim em Israel e apesar do pequeno número de habitantes envolvidos nas atividades nos kibutzim, estes sempre exerceram um importante papel geopolítico e econômico para Israel. O primeiro kibutz foi fundado nos arredores de Tiberíades, 
na costa sudoeste do Mar da Galileia, por judeus russos, em 1909, em meio ao movimento sionista. Recebeu o nome de Degânia.

Os primeiros kibutznikim, como são chamados os membros da comunidade, foram determinantes para a geopolítica do sionismo na região da Palestina e os kibutzim representaram a primeira casa para os imigrantes e contribuíram para a demarcação das fronteiras e ocupação do território. Atualmente, os kibutznikim continuam desenvolvendo sua hospitalidade, desta vez, na economia. Aliam seus espaços verdes, em meio a natureza e a agricultura, para receber os turistas que desejam desfrutar a experiência de conviver com o cotidiano em um kibutz. O papel econômico do kibutz é relevante, também, na produção e abastecimento de produtos agrícolas para o consumo da população e para o abastecimento nas redes hoteleiras. A principal técnica agrícola desenvolvida no kibutz é a produção em estufas que oferece ao país alta produtividade e qualidade dos produtos, além da produção em pequenos espaços e o alto aproveitamento do recurso hídrico, sempre escasso nas regiões do Oriente Médio.

\subsection{Cidades históricas nas margens do Mar da Galileia}

No tempo do Novo Testamento, nas proximidades do Mar da Galileia, ficavam cidades importantes como Carnafaum, Tiberíades, Magdala, Corazim e Betsaida.

\subsubsection{Carnafaum, a cidade de Jesus ${ }^{6}$}

O nome, Carnafaum, origina-se de Kefar Nahum (do aramaico) e significa "vila ou aldeia de Naum”. Está citada apenas no Novo Testamento, por isso, torna-se difícil associá-la ao profeta Naum. Segundo Kaefer (2012), provavelmente, o seu nome está associado ao tipo de solo originado do basalto negro. Situa-se na margem norte do Lago ou Mar da Galileia (Mateus 4:13-18; 9,1) ou Lago de Genesaré (Mateus 14:34; Lucas5:1) ou Mar de Tiberíades (João 6:1-21), no noroeste da Palestina.

Atualmente Carnafaum é conhecida como a 'cidade de Jesus' (Mateus (9:1). Ele habitou ali durante sua vida pública, realizou a maioria de seus milagres e muitas de suas pregações. No tempo de Jesus, Carnafaum era uma das aglomerações humanas ao longo da 'Via Maris' (Caminho do Mar), rota comercial intensamente utilizada pelos mercadores, ligava o Egito em

\footnotetext{
${ }^{6}$ Os referenciais históricos foram baseados em ACHEN, Dom. A Terra Santa de Jesus. Jerusalém: Doko Media Ltd. 2010, e situados no contexto bíblico do Novo Testamento.
} 

e-ISSN 2016/Atual: 2525-7870 | e-ISSN 2015/2016: 2447-018X

direção a Síria e Mesopotâmia (HARTMANN, 2015). A presença de um destacamento de soldados romanos em Carnafaum (Mateus 8:5-13), (Lucas 7:1-10) mostra a importância do povoado como lugar de trânsito de mercadorias, de viajantes e o controle do Império Romano.

No século VII, ano de 665 d.C., grande parte de Carnafaum é destruída por um terremoto e a partir disso tornou-se um vilarejo sem importância e, gradativamente, transformou-se num conjunto de ruínas. Os vestígios foram recuperados pelos franciscanos, em 1894, quando adquiriram o pedaço de terra em que ficava a bíblica cidade de Jesus e promoveram as primeiras escavações. Com intenso trabalho arqueológico foi trazida à evidência a antiga Carnafaum (figura 6 a e b), que se estendia por trezentos metros ao longo da costa do Mar da Galileia, de leste a oeste, e por outros duzentos metros para o interior, em direção norte. A máxima expansão de Carnafaum ocorreu após o declínio do Império Romano, e coincidiu com a época bizantina, especialmente, na segunda metade do século V (HARTMANN, 2015).

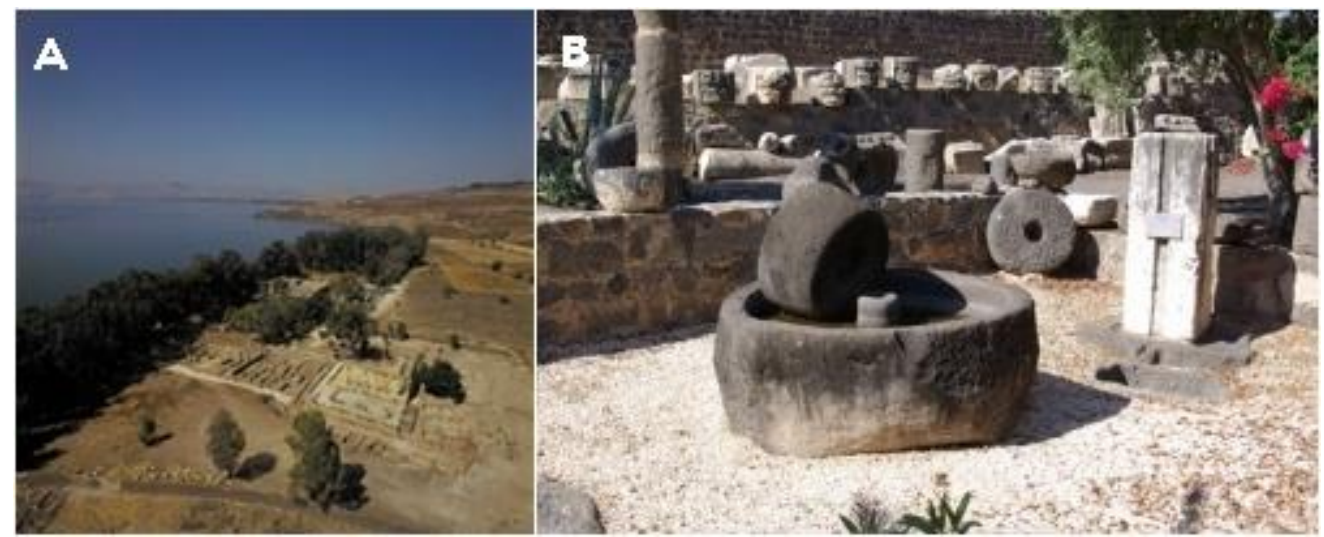

Figura 6a) Vista aérea das escavações de Carnafaum; 4b) Moinhos de farinha e lagares de azeite de oliva. Fonte: Custódia da Terra Santa. Fotos de Stanislao Loffreda e Berthold Werner, respectivamente.

Os habitantes de Carnafaum levavam uma vida de trabalho, sem luxos ou refinamentos como demonstram as ruínas das casas, construídas com pedra de basalto (abundante no local), unidas com argamassa e cobertas com ramagens secas. Cultivava-se o trigo e produzia-se azeite de oliva. Hoje é possível apreciar as diversas pedras para moer os grãos de trigo, pequenas prensas de azeitonas para extrair seu óleo (figura 4b), usadas de forma coletiva pelas famílias que ali habitavam (HARTMANN, 2015).

Em Carnafaum também viveu Pedro e sua família. Sua casa foi uma interessante descoberta, pois desde o século I do Cristianismo foi transformada em 'igreja doméstica'. Em fontes judaicas revela-se que em Carnafaum existia um pequeno grupo de hereges, chamados Minim, porque haviam abandonado o judaísmo ortodoxo para aderir ao cristianismo. Eles mantiveram a memória da casa de Pedro, o apóstolo, que com o tempo se tornou um lugar de culto, uma 'igreja doméstica'. Durante o avanço do Império Bizantino, a 'igreja doméstica' 

e-ISSN 2016/Atual: 2525-7870 | e-ISSN 2015/2016: 2447-018X

desapareceu e sobre ela foi construída, na segunda metade do século $\mathrm{V}$, uma igreja bizantina em forma octogonal, que ficou completamente destruída com o terremoto em 665 d.C. (CUSTÓDIA DA TERRA SANTA).

A partir das primeiras escavações realizadas pelos franciscanos e os arqueólogos veio à tona as ruínas de um elegante edifício do século $\mathrm{V}$, estruturado em dois octógonos concêntricos com outro octógono que servia de deambulatório. O pavimento ostentava um mosaico policromado decorado com figuras de vegetais e animais. Em 1968, os arqueólogos encontraram a abside ${ }^{7}$ orientada para leste e uma pia batismal no seu interior, com adornos característicos da arte bizantina. O que restou dela pode ser visto hoje, protegida sob a moderna igreja em forma de barca, inaugurada em 29 de junho de 1990 (CUSTÓDIA DA TERRA SANTA). Esta igreja representa o Memorial de São Pedro e foi construída sobre a casa e a basílica bizantina. É uma igreja octogonal suportada por grandes pilares que a separam do solo e isso permite aos turistas, peregrinos e visitantes observar os vestígios arqueológicos tanto do exterior do templo, passando por baixo, como do interior, através de óculo quadrangular aberto no centro da nave (figura7a).

\footnotetext{
${ }^{7}$ Abside é um termo arquitetônico que significa arco ou abóbada. É a ala de um edifício, geralmente religioso, que se projeta para fora de forma semicilíndrica ou poliédrica e em que o remate superior é, geralmente, uma semicúpula.
} 
RELACult - Revista Latino-Americana de Estudos em Cultura e Sociedade

Revista Latinoamericana de Estudios en Cultura y Sociedad | Latin American Journal of Studies in Culture and Society

V. 03, no 02, mai-ago., 2017, p. 77-100| relacult.claec.org e-ISSN 2016/Atual: 2525-7870 | e-ISSN 2015/2016: 2447-018X
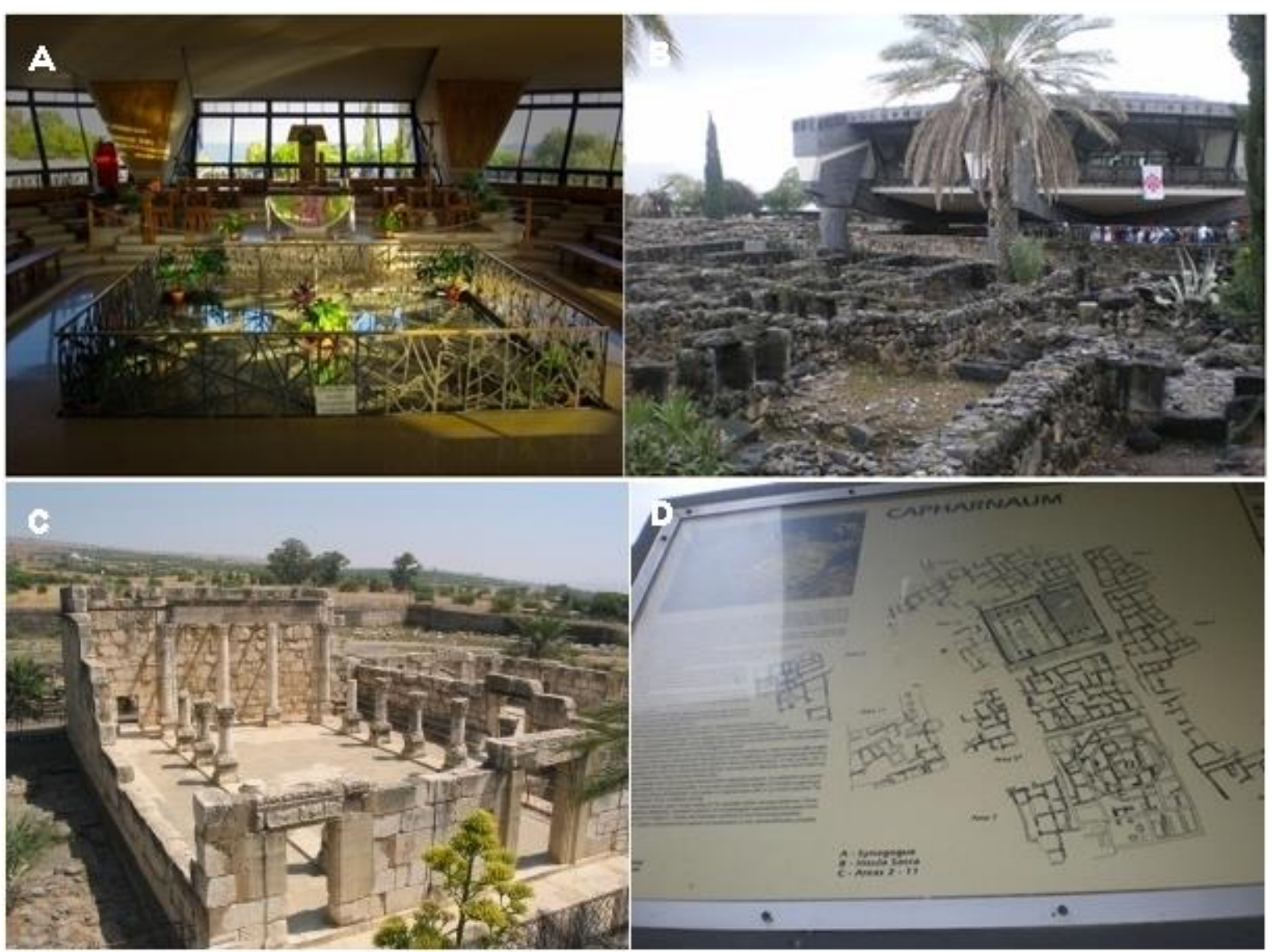

Figura 7. 5a) O óculo no centro da igreja para observar os vestígios da casa de Pedro;7b) vestígios da casa de Pedro e vista parcial da igreja para observação; 7c) a sinagoga com blocos de calcário, vista do sul, onde se localizava a entrada principal. No leste avista-se o átrio adicionado no século V; 7d) mapa de reconstituição do complexo arquitetônico de Carnafaum

Fonte: Custódia da Terra Santa (fotos 7a e 7c de Lidian Strzedula e Jerzy Kraj, respectivamente). Arquivo pessoal (fotos $7 \mathrm{~b}$ e7d).

Além da casa de Pedro e da basílica bizantina, chama atenção a ruína da monumental sinagoga, local de culto judaico, de arquitetura muito bela e com elementos decorativos, ricamente lavrados e esculpidos como cornijas e capitéis. Também chama atenção a magnitude da construção feita com blocos quadrados de pedra calcária branca (figura 5c), bem diferente das demais casas de Carnafaum, com suas paredes negras de pedra basáltica. Esta sinagoga não é aquela onde se realizaram inúmeras pregações e prodígios de Jesus, mas sua construção pertence a um período posterior. Os estudos arqueológicos sustentam que o edifício principal e um outro grande recinto ao norte teriam sido erguidos no final do século IV, e que foi acrescentado um átrio no lado oriental em meados do século V. No entanto, os mesmo estudos e escavações confirmaram que o complexo arquitetônico da monumental sinagoga se apoia sobre os restos de outras, entre quais estaria a sinagoga anterior, bem menor. $\mathrm{O}$ indício mais notável consiste no amplo pavimento de pedra do século I, descoberto sob a nave central (CUSTÓDIA DA TERRA SANTA). 
RELACult - Revista Latino-Americana de Estudos em Cultura e Sociedade

Revista Latinoamericana de Estudios en Cultura y Sociedad | Latin American Journal of Studies in Culture and Society

V. 03, no 02, mai-ago., 2017, p. 77-100| relacult.claec.org e-ISSN 2016/Atual: 2525-7870 | e-ISSN 2015/2016: 2447-018X

A cidade, em seu conjunto histórico, apresenta grande apelo turístico, tanto pelo apelo místico quanto cultural, especialmente, para o judaísmo e para o cristianismo.

\subsubsection{Tiberíades, a cidade da água ${ }^{8}$}

Tiberíades foi construída no ano 18 d.C. pelo tetrarca Herodes Antipas, perto das termas de Hammat, fontes naturais de água quente, onde ainda hoje a água sulfurosa sai de grande profundidade da Terra a uma temperatura de 65 graus, e continua sendo usada para atrair turistas e pessoas em busca de tratamento para diversas doenças reumáticas.

O nome Tiberíades foi dado em homenagem ao Imperador de Roma, Cláudio Tibério, que neste período detinha o poder sobre a região e os tetrarcas, como Herodes Antípas ${ }^{9}$, eram considerados reis por cortesia (obrigação) do povo, mas não passavam de príncipes tributários. Esses príncipes eram judeus e estavam na região, por concessão, do Imperador de Roma, para oprimir, fiscalizar e receber tributos e, então, poderiam ser chamados de reis pelo povo.

Tiberíades localiza-se a 212 metros abaixo do nível do mar, às margens do Mar da Galileia, em frente as Colinas de Golã, que Israel conquistou na Síria, na Guerra dos Seis Dias, em 1967.

No ano 70 d.C., logo após a destruição de Jerusalém e do Templo, ordenada pelo comandante romano Tito, a Galileia tornou-se um centro espiritual do Judaísmo e muitos rabinos e sacerdotes se transferiram para Tiberíades.

No ano de 135 d.C., com a outra grande destruição de Jerusalém, desta vez ordenada pelo imperador Adriano, também o Sinédrio ${ }^{10}$ se transferiu para Tiberíades e iniciando as grandes escolas rabínicas, das quais sairá a Lei do Judaísmo, conhecida com o nome de Talmud $^{11}$, no século IV. O Talmud interpreta os livros também existentes no Velho Testamento,

\footnotetext{
${ }^{8}$ Os referenciais históricos foram baseados em ACHEN, Dom. A Terra Santa de Jesus. Jerusalém: Doko Media Ltd. 2010, e situados no contexto bíblico do Novo Testamento.

9 Herodes Antípas é o rei da Galileia, do martírio de João Batista e do processo de Jesus. A Galileia estava sob a administração de Herodes Antípas e a Judeia (onde fica Jerusalém) era administrada pelo governador romano Pôncio Pilatos. O imperador romano era Tibério, chamado de Tibério Cláudio Nero César (foi imperador romano de 14 d.C. até 37 d.C.

10 Sinédrio era um conselho supremo do Judaísmo e a sede máxima localiza-se em Jerusalém.

11 Talmud é um livro sagrado dos judeus. É um registro das interpretações e discussões dos rabis que pertencem à lei, ética, costumes e história do judaísmo. É um texto de referência para o judaísmo rabínico.
} 
servindo de guia para a vida judaica. A cidade transformou-se assim num importante centro político, espiritual e cultural para o Judaísmo. Em 636 a cidade é ocupada pelos árabes, mas a comunidade judaica continua a existir sob o governo árabe e até sob as Cruzadas, no período de 1100 a 1247. Um violento terremoto, em 1837, provocou grandes danos e a morte de muitos judeus.

A partir do século XX a colonização judaica da Galileia dá um novo impulso à cidade com o estabelecimento de uma comunidade judaica moderna e, com a formação do Estado de Israel, em 1949, Tiberíades passa a ser uma importante cidade de referência para o Judaísmo.

Há na cidade, junto ao lago, uma pequena igreja franciscana, dedicada a São Pedro. Foi construída em 1879 sobre as ruínas de outra do tempo das Cruzadas, no século XII, e tem afrescos alusivos ao episódio do Evangelho que relata a pesca milagrosa.

A principal atividade econômica é o turismo, especialmente, durante a primavera e o inverno, aproveitando as águas termais. Além disso, é uma importante referência cultural para os judeus que ali encontram sepulcros e túmulos venerados de grandes mestres ou rabis.

\subsubsection{Magdala, terra de Maria Madalena ${ }^{12}$}

O nome, Magdala, em hebraico, é 'Migdal' e quer dizer “torre”. Os gregos a denominavam de 'Tarichea', que quer dizer "peixe salgado", indicando que ali existia um mercado de peixe em conserva. Em Magdala, além do porto, havia uma indústria de construção de barcos e havia concentração de riqueza e o excessivo bem estar levou à corrupção dos costumes. Foi destruída em 70, por Tito, e deixada em ruínas juntamente com outras cidades judaicas. Pela grande quantidade de moedas antigas encontradas nas escavações, inferiu-se que era movimentado o comércio entre Magdala e as outras cidades ao logo da 'Via Maris'.

Magdala, no referencial do cristianismo é conhecida como a Terra de Maria Madalena ou Maria de Magdala, donde lhe veio o nome de Madalena. Maria Madalena já foi tratada como "a prostituta arrependida", mas não há referência desta condição nos Evangelhos. Madalena é citada cinco vezes no Novo Testamento (Lucas 8:2-3), (Marcos 15:40), João 19:25), (Marcos 15:47), (Marcos 16:1), (João 20:18) e (Mateus 28:9-10). A primeira vez que aparece é citada no evangelho de Lucas, quando diz que Jesus viajava, pregando em todas as partes,

\footnotetext{
12 Os referenciais históricos foram baseados em ACHEN, Dom. A Terra Santa de Jesus. Jerusalém: Doko Media Ltd. 2010, e situados no contexto bíblico do Novo Testamento.
} 
acompanhado pelos doze discípulos e por algumas mulheres, entre elas, Maria, chamada Maria Madalena.

Nas atuais rotas turísticas da Terra Santa e, especialmente, da Galileia, a cidade de Magdala é um pequeno centro urbano entre Tiberíades e Carnafaum e, ultimamente, objeto de intenso trabalho de escavações arqueológicas. Magdala dista $7 \mathrm{Km}$ de Carnafaum e nos Evangelhos não é mencionada em relação a alguma visita de Jesus, apesar de ter sido uma florescente cidade, de grande movimento comercial.

\subsubsection{Corazim, a cidade incrédula ${ }^{13}$}

Corazim foi uma pequena cidade ao norte de Carnafaum, no Mar da Galileia, localizada em uma colina próxima do Monte das Bem Aventuranças. As cidades de Carnafaum, Betsaida e Corazim formavam o conhecido "triângulo evangélico" decorrente do intenso trabalho de evangelização de Jesus e seus discípulos. Nestas cidades decorreu significativa parte da vida pública de Jesus e a população de Corazim e Betsaida é conhecida, nos Evangelhos, pela insurgência e pela incredulidade para com as pregações de Jesus (Lucas 10:13-16) e (Mateus $11: 20)$.

A cidade e seu entorno é descrita como uma excelente região produtora de trigo nos livros do Talmud, mas nunca é descrita pela grande prosperidade e permaneceu como uma pequena vila até o século VI. Depois, é descrita alternando períodos de abandono da população e permanecendo, no local, apenas alguns poucos pescadores judeus.

As primeiras expedições arqueológicas ocorreram no início do século XX que foram realizadas pela Universidade Hebraica de Jerusalém. Por questões políticas foram retomadas na década de 1960 e novas investidas ocorreram na década de 1980 e, após estas explorações de pesquisa, o local foi preparado para o turismo, com instalações, sinalizações e gestão administrativa.

Em Corazim localiza-se uma das sinagogas mais antigas existentes na Terra Santa e sua construção foi realizada com pedras vulcânicas da região do Mar da Galileia (basalto negro). Os visitantes podem observar o piso original bem como as pedras que serviam de trono onde se sentavam os altos líderes da comunidade judaica (figura 8a). Nas ruínas preservadas os turistas

\footnotetext{
13 Os referenciais históricos foram baseados em ACHEN, Dom. A Terra Santa de Jesus. Jerusalém: Doko Media Ltd. 2010, e situados no contexto bíblico do Novo Testamento.
} 
RELACult - Revista Latino-Americana de Estudos em Cultura e Sociedade

Revista Latinoamericana de Estudios en Cultura y Sociedad | Latin American Journal of Studies in Culture and Society

V. 03, no 02, mai-ago., 2017, p. 77-100| relacult.claec.org e-ISSN 2016/Atual: 2525-7870 | e-ISSN 2015/2016: 2447-018X

também podem observar as pedras de basalto que serviam de moinho (figura 8b) para moer os grãos de trigo que era um cultivo abundante na região na Idade Antiga.

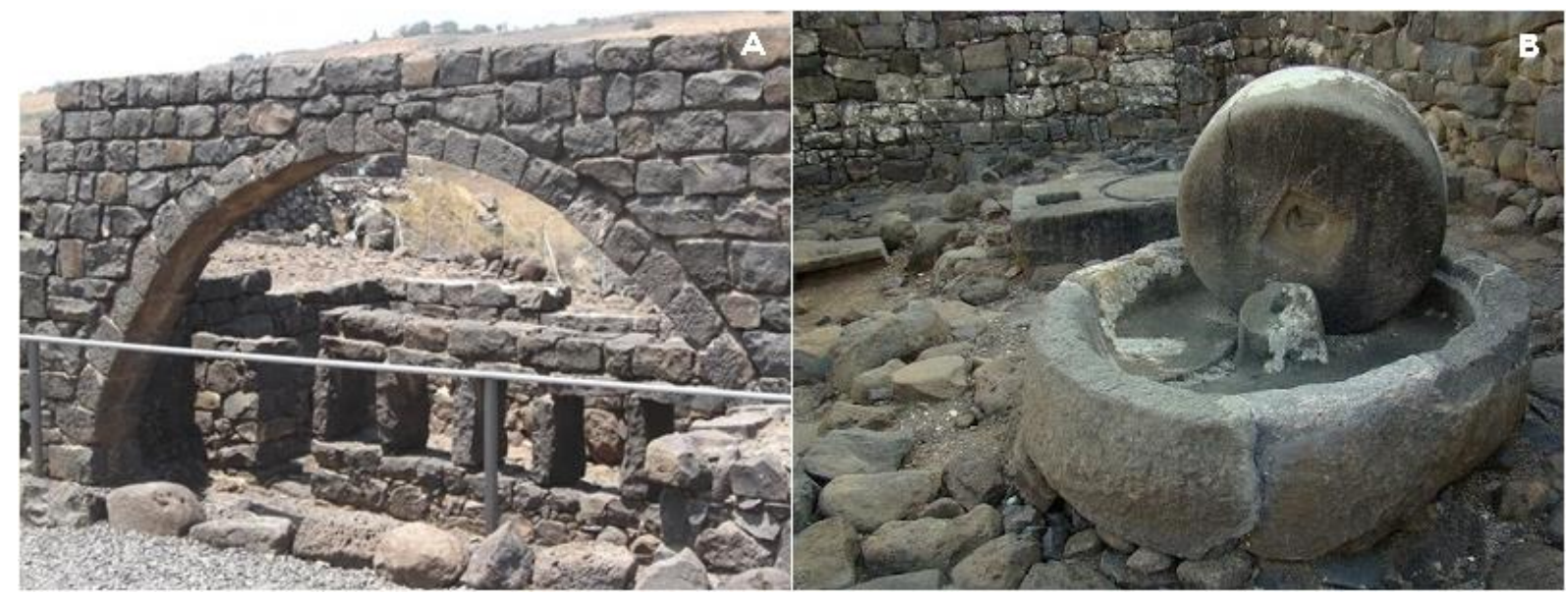

Figura 8. 8a) Ruína de sinagoga judaica em Corazim, construída com basalto negro; 8b) Moinhos de farinha de trigo. Fonte: Ministério do Turismo de Israel (2013).

Corazim é, assim, uma pequena cidade, um importante sítio arqueológico do Estado de Israel e um atrativo turístico na Terra Santa. O principal recurso econômico da cidade advém do turismo, seja, por meio da cobrança de ingressos nos sítios arqueológicos, da gastronomia e de souvenirs.

\subsubsection{Betsaida, casa da pesca ${ }^{14}$}

Betsaida era uma vila da história da vida terrena de Jesus, situada a nordeste do Mar da Galileia. Infere-se que, no século VII, ano de 665 d.C., quando grande parte de Carnafaum é destruída por um terremoto, um cataclisma atinge a área de Betsaida que sobre grande inundação.

De acordo com os Evangelhos, os apóstolos Pedro, André e Felipe eram pescadores e naturais de Betsaida (João 1:44) e foram chamados para a obra de Jesus. Ainda segundo os Evangelhos, Betsaida também foi o local de um dos principais milagres de Jesus, a multiplicação dos pães e dos peixes, dado que o apóstolo João reporta como cinco pequenos pães de cevada e dois peixinhos, fornecidos por alguém do povo e que foram utilizados por

\footnotetext{
${ }^{14}$ Os referenciais históricos foram baseados em ACHEN, Dom. A Terra Santa de Jesus. Jerusalém: Doko Media Ltd. 2010, e situados no contexto bíblico do Novo Testamento.
} 
Jesus para alimentar a multidão estimada em cinco mil pessoas. Este relato aparece nos quatro evangelhos (Mateus 14:13-21), (Mateus 6:31-44), (Lucas 9:10-17) e (João 6:5-15).

De acordo com os quatro evangelistas, Jesus retirou-se, solitariamente, para Betsaida, de barco, pelo Mar da Galileia, quando soube que João Batista havia sido morto por ordem de Herodes Antípas, rei judeu da Galileia. A multidão seguiu Jesus a partir de vilarejos e cidades próximas, como Carnafaum e Corazim e quando Jesus desembarcou em Betsaida e viu a multidão, se compadeceu e realizou curas e pregações.

Ao anoitecer, os discípulos se aproximaram de Jesus e o alertaram dizendo: "“Este lugar é deserto e a hora é já passada; despede, pois, as multidões, para que, indo às aldeias, comprem alguma coisa para comer". Jesus respondeu: "Não precisam ir; dai-lhes vós de comer". Os discípulos retrucaram: Não temos aqui senão cinco pães e dois peixes" e Jesus pediu-lhes que trouxessem os pães e os peixes. Jesus então ordenou ao povo que se sentasse na grama. Tomando os cinco pães e dois peixes e olhando para o céu, ele agradeceu e partiu os pães. Então ele os deu para os discípulos e eles os deram para o povo. Todos puderam comer e se satisfizeram, sobrando ainda aos discípulos doze cestos com pedaços de pão. O número dos que comeram era cinco mil homens, além das mulheres e crianças (Marcos 6:32-44).

É adequado sublinhar a pedagogia de Jesus, ao realizar o milagre, reparte os cinco pães e dois peixes, que alguém do povo tinha consigo. Podia ter feito tudo sozinho, mas mostra a importância de contar com a colaboração do outro.

Não somente peregrinos querem conhecer lugares como Betsaida e outros lugares por onde Jesus andou na Terra Santa. As atrações turísticas são muitas no entorno do Mar da Galileia, tanto a natureza como a arqueologia e a história. Assim, há investimentos nas redes hoteleiras no entorno do Mar da Galileia, com restaurantes e resorts.

\section{Metodologia}

A metodologia está embasada em revisão bibliográfica sobre o tema, na perspectiva da pesquisa qualitativa que relaciona a cultura e a religião como interação entre a interpretação e a experiência no sagrado e a atividade do turismo.

A observação de campo foi realizada em dois momentos, em uma viagem de turismo (fevereiro de 2013) e em uma peregrinação (junho de 2014).

\section{Contextos e discussões sobre Mar da Galileia e seus simbolismos}

A região do Mar da Galileia e seu entorno integra uma terra que já foi dominada por egípcios e babilônios, filisteus e assírios, persas e gregos, romanos e bizantinos, árabes e 
cruzados, turcos e ingleses. E agora, nesse local, convivem em grande tensão palestinos e israelenses.

O Mar da Galileia e seu entorno no contexto bíblico apresenta um rico cenário de interpretação da Geografia Cultural. Moreira (2012) entende que o "código de linguagem" da existência humana está inscrito na relação que o indivíduo estabelece com o local onde vive e, de forma mais específica, inscreve na arquitetura da cidade. Corrêa; Rosendahl (2010) veem a paisagem cultural como comunicação e como forma de expor o que se é, ou o que se deseja ser.

Entre as cidades do entorno do Mar da Galileia encontram-se aquelas que se destacaram no período inicial do cristianismo, como Carnafaum, Tiberíades, Magdala, Corazim e Betsaida. A paisagem urbana destas cidades foi (e continua sendo) resultado das ações da sociedade, em diferentes períodos históricos, colocando significados que caracterizam a cultura, a política, a economia e, consequentemente, a sociedade que a produz como reflexo de sua existência. Assim, a paisagem em torno do Mar da Galileia passa a ser um produto da cultura que a sociedade como um todo exerceu (e exerce) em suas ações e conflitos e, especialmente, na relação com o sagrado.

O Mar da Galileia e seu entorno tem forte significado simbólico, religioso e cultural para os judeus e para os cristãos, principalmente. No entanto, mesmo quem não é cristão conhece a histórica caminhada de Jesus sobre as águas, o tempo em que Ele viveu entre pescadores e a famosa multiplicação de pães e peixes para mais de 5 mil pessoas. O cenário dessas importantes passagens bíblicas ainda existe: o Mar da Galileia, também conhecido como Mar de Tiberíades, ou ainda Lago de Genesaré ou Guinossar é abastecido pelo rio Jordão, o mesmo no qual Jesus foi batizado por seu primo João Batista, filho de Isabel e este cenário se enche de significados e relações com o sagrado.

A atração de pessoas a esses centros, na atualidade, é motivada pelo estímulo espiritual. A condição econômica que sustenta estas cidades hoje é o turismo e este apoia-se na existência das ruínas dos centros cerimoniais ou pela história de prováveis acontecimentos e de códigos espirituais creditados aos locais pelos relatos históricos e religiosos. A ideia religiosa e espiritual está intimamente relacionada à história humana do Mar da Galileia e às cidades que surgiram no seu entorno. Da mesma forma, o sagrado e o profano coexistem nos locais e representam de maneira clara a dualidade durkheimiana: diferença entre sagrado e profano. Nas cidades e nos seus roteiros turísticos, as pessoas comuns (os turistas e os peregrinos) se transformam, distinguindo o "excepcional” do "cotidiano" (DURKHEIM, 1989, p. 366).

Os visitantes e, em especial, os peregrinos imprimem no espaço um extraordinário estado de efervescência religiosa e/ou de fé independente de credo religioso. É através dessa 
vivência com o sagrado que o peregrino e visitante pode ter acesso a uma realidade que transcende o tempo e o mundo terreno. A experiência de fé é, então, visível, torna-se emocionante e revela um simbolismo marcante, que ultrapassa qualquer concepção, seja ela tradicional (do fiel praticante) ou pós-moderna (do fiel sem vínculo religioso), de experiência espiritual. A principal evidência a ser buscada é "ver" o sagrado na paisagem e vivenciar o sentido cósmico da existência de Deus no mundo, manifestando-se na natureza, a exemplo, do Mar da Galileia que estabelece um sistema de relações entre o homem e a fé, e suas práticas materializadas no espaço geográfico. Os Evangelhos são pródigos em relatos confirmados por historiados e evidenciadas pelas ruínas arqueológicas de que a manifestação do divino ocorreu e a evidência pode ser buscada nos dias atuais nos locais que constituem o território da espiritualidade da Galileia.

Pode dizer-se que o turismo contribui para o desenvolvimento dos valores espirituais que representam a indicada dualidade durkheimiana: diferença entre sagrado e profano. $\mathrm{O}$ tempo na religião e na vida profana divide-se, genericamente, nessa dualidade. Na religião existe o tempo sagrado, dedicado aos atos religiosos ou rituais, e o tempo profano. A vida profana divide-se em tempo de trabalho e em tempo de lazer. Tanto no tempo e espaço sagrado, como no tempo e espaço de lazer, o homem procura o equilíbrio, tenta encontrar forças e conhecimento, para mais um período profano de trabalho (SECALL 2009).

No Mar da Galileia e seu entorno o sagrado e o profano coexistem, porém torna-se difícil distinguir os seus limites. O sagrado está no local (uma colina, por exemplo), onde o símbolo da devoção e se abriga na igreja construída no local para a realização dos ritos de fé. O espaço profano é o entorno, o espaço destinado ao comércio e ao lazer e, segundo Rosendahl (2009, p. 49), "numa espetacular mescla entre cerimônia religiosa e atividades profanas".

A organização espacial do entorno do Mar da Galileia obedece e evidencia a lógica da dualidade durkheimiana. Existe o local, de relato bíblico ou do Talmud, que representa o centro cósmico, qualificadamente forte, definido e consagrado onde ocorre visivelmente o encontro simbólico entre o fiel com o divino. Para Halbwachs (1950, p. 12), nestes locais, a particularidade "é que, embora Deus esteja em toda a parte, há locais privilegiados em que Ele se manifestou e basta que os fiéis queiram comemorar tal evento para que essas lembranças efetivamente preservadas no imaginário religioso" ${ }^{\prime 2}$.

O sagrado imprime no espaço um extraordinário estado de efervescência religiosa dos fiéis a ponto de que a vivência com o sagrado que o peregrino estabelece transcende o tempo e

\footnotetext{
15 Traduzido pela autora.
} 
as coisas não se restringem ao concreto. Há uma manifestação contundente da espiritualidade e segundo Durkheim (1986, p. 492) “as energias vitais estão supraexcitadas, as paixões mais vivas, as sensações mais fortes - existem mesmo algumas que não se produzem senão neste momento". Rosendahl (2009, p. 46), acrescenta que "é comum os milagres ocorrerem nessas ocasiões".

Existem, nestes locais, no entorno do Mar da Galileia, uma extensão e uma parte contínua, periférica ao centro cósmico, não sagrada, onde vivem as pessoas do comércio, do abastecimento, dos resorts, do turismo, enfim. Para Rosendahl (2009), locais cósmicos e transações comerciais sempre foram atividades associativas.

Existe uma inter-relação entre o espaço sagrado e o profano; entretanto, eles não se misturam. A separação essencial entre sagrado e profano se realiza materialmente no espaço.

No turismo, corpo e espírito humano restabelecem-se da fadiga do trabalho e do ritmo cotidiano da vida. O homem reafirma a sua necessidade vital de liberdade e movimento, e estabelece relações interpessoais num contexto de serenidade particular, de maior confiança e disponibilidade para o reencontro e o diálogo consigo mesmo. A separação entre o sagrado e o profano no fazer do turista não é passível de uma distinção tão marcante. O turista participa do culto ou da liturgia do ato sagrado e, ao mesmo tempo, é arrebatado pelo conforto do lazer nos resorts ou pelo comércio local. Há, então, uma espetacular mescla entre cerimônia religiosa e atividades profanas. $\mathrm{O}$ culto, a liturgia, a oração, o silêncio, a contemplação representam a marca do sagrado oficial. As danças, as compras, as bebidas, as conversas fúteis, os "selfies" testemunham o profano.

Existe uma inter-relação entre o espaço sagrado e o profano; entretanto, eles não se misturam, mas nas relações humanas, se complementam. A inter-relação entre sagrado e profano se realiza nas relações humanas, especialmente, entre nativos do local e os peregrinos e os turistas (visitantes).

No Mar da Galileia há evidências destas inferências, ou seja, a separação essencial entre sagrado e profano se realiza materialmente no espaço, mas a complementaridade entre o sagrado e o profano se efetivas nas relações humanas existentes na atividade turística. Ao redor do Mar da Galileia estão importantes cidades, também palcos de célebres passagens bíblicas e berços de importantes personagens que conviveram com o próprio Redentor. Na região, pelo menos cinco apóstolos nasceram e viveram, assim como Maria Madalena. Ali também aconteceu o Sermão da Montanha. Foi nas margens do Mar da Galileia que Jesus recrutou seus apóstolos entre os pescadores: Simão (rebatizado Pedro), seu irmão André, Felipe e outros dois irmãos, João e Tiago. As mesmas águas foram acalmadas pelo próprio Jesus em meio a uma 
grande tempestade, à qual ele pôs fim. Após este episódio, chegando à margem, o Messias libertou dois possuídos, expulsando os demônios que estavam neles e mandando-os para uma manada de porcos ali próximos, que se jogaram de um barranco, nas águas (Mateus 8:28-33). O mesmo barranco está assinalado até hoje e é visitado por muitos cristãos.

Também o Mar da Galileia é o mesmo e hoje está assinalado pelo turismo. A região atrai muitos turistas devido à importância bíblica, mas também por sua grande beleza natural. De alguns ângulos, é possível ver montanhas contracenando com o lago, o que torna a vista ainda mais bonita.

Em suas margens estão instalados os resorts, onde é possível relaxar e renovar-se física e mentalmente. Também há alguns hotéis-fazenda na região são muito procurados pelos que buscam tranquilidade longe das grandes metrópoles. E existe a oportunidade de conviver com a proposta comunitária existente nos kibutzim.

A prática de esportes aquáticos no Mar da Galileia é muito comum. Barcos a vela, jetski e esqui aquático agitam a calmaria da região, bem como pessoas que procuram o lago para praticar nado. A Competição do Kineret é o maior evento de natação de Israel, realizada anualmente em setembro, reunindo os especialistas dessa modalidade esportiva.

Os ‘Sea Rangers', um movimento juvenil bem ativo em Israel, têm uma de suas unidades no Lago da Galileia. Além de cuidarem da região, os jovens ensinam a moradores e turistas a melhor forma de coexistir com a natureza, conservando-a e protegendo-a.

O Mar da Galileia revela diferentes cenários e perspectivas a partir de sua história e a cultura do seu entorno, que lhe confere um privilegiado encontro do homem com o divino, de uma forma quase impossível em outro lugar. É capaz de despertar sensações, sentimentos, emoções, surpresas, maravilhas que darão ao peregrino uma surpreendente experiência de serenidade. O que torna belo o contato do peregrino não é apenas o que ele vê, mas, sobretudo, o sinal que fica no íntimo a partir da vivência com o sagrado.

\section{Conclusão}

O Mar da Galileia e seu entorno é uma terra de contrastes de religiões, de culturas, de línguas, de povos e ritos, de tensões vivas e palpáveis, de luta pela terra, dos lugares sagrados; de perfumes, sons, cantos, flores, deserto, água e cenários carregados de simbolismos. Não é uma terra a mais que os peregrinos e os turistas visitam para fotografar, para conhecer monumentos históricos, para receber somente alguns conhecimentos de história, geografia, arqueologia e cultura geral. Mas para fazer uma experiência com o sagrado. 
A atividade turística é intensa e, atualmente, é responsável pela manutenção econômica da população, seja na agricultura ou na prestação de serviços.

Os peregrinos e, também, os turistas buscam a experiência de fé que, no Mar da Galileia e seu entorno, é visível na geografia e nas ruínas das antigas cidades de Carnafaum, Tiberíades, Magdala, Corazim e Betsaida. Atualmente, estes locais mantêm o comércio e a prestação de serviços para atender a grande demanda de peregrinos e de turistas. O sagrado e o profano coexistem, porém torna-se difícil distinguir os seus limites. O sagrado está nos símbolos que são abrigados pelas igrejas construídas no local para a realização dos ritos de fé. O espaço profano é o entorno, o espaço destinado ao comércio e ao lazer.

Assim, infere-se que existe uma inter-relação entre o espaço sagrado e o profano; entretanto, eles não se misturam nas relações humanas, se complementam. A inter-relação entre sagrado e profano se realiza nas relações humanas, especialmente, entre nativos do local e os peregrinos e os turistas.

\section{Referências}

ACHEN, Dom. A Terra Santa de Jesus. Jerusalém: Doko Media Ltd. 2010.

BÍBLIA. 1993. A Bíblia Sagrada: Antigo e Novo Testamento. Traduzida em português por João Ferreira de Almeida. 2. ed. ver. e atual no Brasil. São Paulo: Sociedade Bíblica do Brasil, 1993.

CLAVAL, Paul. Geografia Cultural. Florianópolis: EDUSC. 2000.

CORRÊA, Roberto Lobato. Territorialidade e Corporação: Um exemplo. In: SANTOS, Milton; SOUZA, Maria Adélia. A. SILVEIRA, M. L. (org.). Território: Globalização e Fragmentação. São Paulo, HUCITEC/ANPUR, 1993.

CORREA, Roberto Lobato; ROSENDAHL, Zeny (Orgs.). Economia, Cultura e Espaço. Rio de Janeiro: Ed. UERJ, 2010.

CUSTÓDIA DA TERRA SANTA. Disponível em http://www.capernaum.custodia.org/ Acesso em 12 de jan de 2017.

DURKHEIM, Emile. As Formas Elementares da Vida Religiosa. Traduzido por Joaquim Pereira Neto. São Paulo: Paulus. 1989.

HALBWACHS, Maurice. La Memóire Colletive. Paris: Presses Universitaires de France. 1950.

HARTMANN, Jorge Egídio. A Terra Santa para além dos muros. Porto Alegre: Odisseia, 2015.

KAEFER, José Ademar. Arqueologia das terras da Bíblia. São Paulo: Paulus, 2012. 

e-ISSN 2016/Atual: 2525-7870 | e-ISSN 2015/2016: 2447-018X

MINISTÉRIO DO TURISMO DE ISRAEL. Disponível em

http://www.goisrael.com.br/Tourism_Bra. Acesso em 21 de jan de 2016.

MOREIRA, Ruy. Pensar e Ser em Geografia: ensaios de história, epistemologia e ontologia do espaço geográfico. São Paulo: Ed. Contexto, 2012.

SECALL, Rafael Esteve. "Turismo y Religión. Aproximación histórica y evaluación del impacto económico del turismo religioso”. Jornadas de Delegados de Pastoral de Turismo. Conferencia Episcopal Española. Disponível em http://www.diocesisoa.org/documentos/pastoralturismo/Esteve,\%20Rafael\%20-\%20texto.pdf. Acesso em 16 de jan de 2017. 